\section{Different directions?}

How independent are the boards of San Diego's high-tech companies? Lisa Bowman investigates the multiple directors.

$\mathbf{T}$ he wave of corporate scandals that dragged down Enron also rolled over the US technology and science companies WorldCom and ImClone. Now savvy investors, corporate governance experts and potential customers are taking a close interest in who sits on a company's board of directors. Are board members independent, or do they have ties to company insiders or positions on other boards?

In the San Diego region, the board of Qualcomm, which makes wireless network equipment and is one of the region's largest tech companies, has at least four members who perform the same role elsewhere. For instance, Ray Dittamore is a director not only of Qualcomm but of the science companies Invitrogen, Gen-Probe and Applied Molecular Evolution. Other technology and science companies in the region with board-hopping directors include Anacomp, SYS Technologies and Science Applications International Corporation (SAIC).

It is hard to quantify exactly what difference directors can make to research and development work in a company. A board is supposed to monitor a company, not meddle in its everyday affairs - but directors can wield significant indirect influence. Although they do not dictate what research is done, they do work with management to set strategies and allocate resources, actions that may result in one project being killed and another spawned.

Like many corporate governance experts, Charles Elson of the University of Delaware

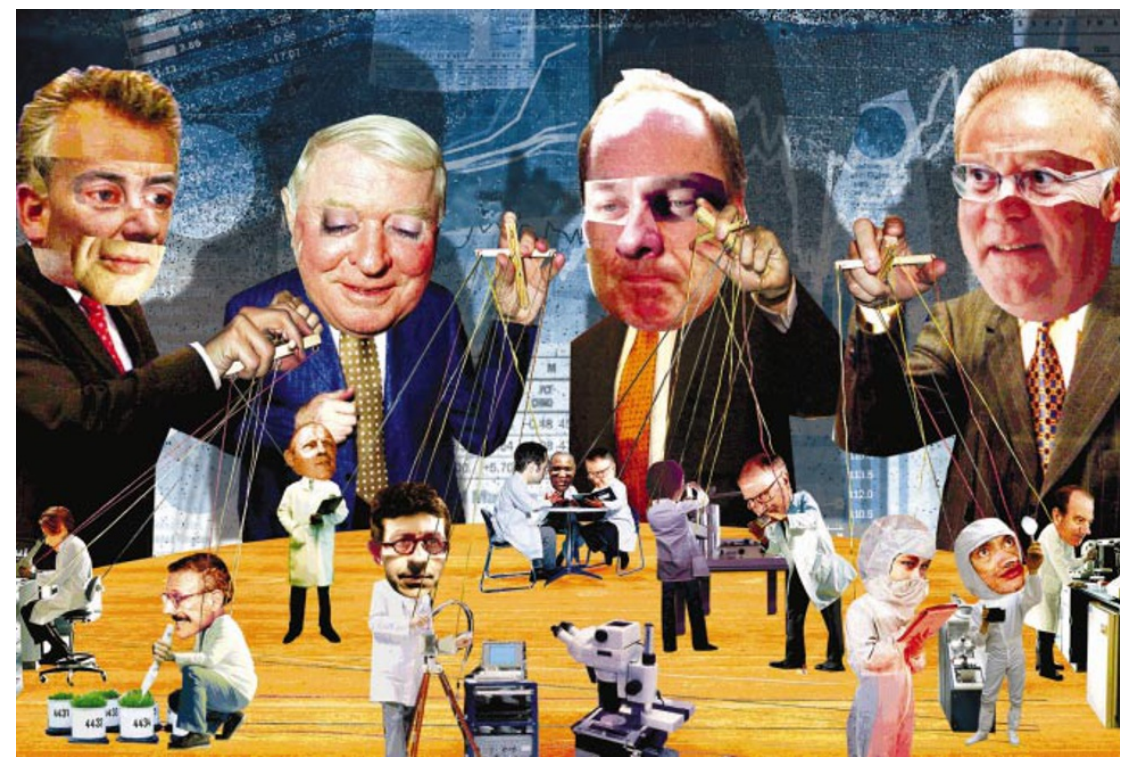

in Newark sees no benefit to multiple directorships. "The more boards you're on, the less effective a monitor you become," he says. "It's a job that takes a lot of time." Many also question whether multiple directors are likely to challenge management decisions. "Are they getting appointed because they're diligent monitors or because they're not boat-rockers?" asks Benjamin Hermalin, a professor of banking and finance at the University of California, Berkeley.

And what do the directors get out of it? Some are corporate go-getters who enjoy helping young companies along. Others are eager for the cachet and power that accompanies a directorship. Then there's the pay: in 2002 an average board member who was not also employed by the company received about $\$ 122,000$ for the year in cash payments (retainers and permeeting fees) and equities (grants of stock, stock options and restricted shares) according to a study of 250 companies from the Standard \& Poor's 500 index, conducted by human resource consultants Towers Perrin.

But there can be some advantages to the practice too. Hermalin says that multiple directorships, although generally not recommended, could lead to collaboration between companies in the quickly changing fields of technology and science. Someone who is familiar with the industry landscape may spot opportunities or partnerships that another would overlook.

Or a director may have other valuable experience, says Larry Stambaugh, chief executive of San Diego-based Maxim Pharmaceuticals and a board member of the Corporate Directors Forum. The forum frowns upon multiple directorships, but Stambaugh says that they may make sense in certain cases, especially if a director is an expert in accounting and oversight. For example, he points out, Dittamore retired after 35 years as a managing partner at accounting firm Ernst \& Young, making him a natural target for companies seeking auditing expertise on their boards.

What's more, says Stambaugh, biotechnology start-ups - of which San Diego is a hotbed - often seek out pharmaceutical executives for their boards. "They have good access to how pharmaceutical companies are thinking, what contacts might be out there, and insight into the commercial drug process," he says. "That knowledge is helpful to a young company."

But the general trend in the United States seems to be against multiple directorships. According to the June issue of business magazine Forbes, the number of people serving on five or more boards at major US companies has declined from 18 to 9 in the past year. Many companies are also starting to limit the number of other boards their directors can sit on.

San Diego companies get particularly high marks for corporate governance. For example, 30 of the top 45 public companies in San Diego have better than average corporate governance practices, according to ratings by Institutional Shareholder Services, which examines corporate leadership for institutional investors.

Stambaugh says that directors are taking their jobs more seriously and putting in much longer hours than they did in years past. "What really changes corporate governance policies is not legislation, it's attitude, energy, putting in time and knowing how to do a good job," he emphasizes.

Lisa Bowman is a freelance writer based in San Francisco. 